\title{
Effect of Glass Powder and GGBS on Strength of Fly Ash Based
}

\section{Geopolymer Concrete}

\author{
Dr. I.R. Mithanthaya \\ Professor, Dept. of civil Engineering, NMAMIT, \\ Nitte, Karkala-574110, India
}

Abstract

In this study, the effect of glass powder (GP) and ground granulated blast furnace slag (GGBS) on the compressive strength of Fly ash based geopolymer concrete has been investigated. The mass ratio of fine aggregate (fA) to coarse aggregate (CA) was maintained constant. $\mathrm{NaOH}$ flakes dissolved in water was used as activating liquid and mixed with fly ash (FA) to produce geopolymer paste or cementing material. This paste was added to mixture of $\mathrm{CA}$ and fA to obtain geopolymer concrete. Cube samples were prepared from this concrete. The ranges of investigation parameters include GP/FA from $0 \%$ to $20 \%$, and GGBS/ FA from $0 \%$ to $20 \%$ with constant amount of GP. All the samples were air cured inside laboratory under room temperature. Compressive strength of cube samples after $\mathbf{7}$ days and 28 days curing were determined. The test results are presented and discussed. Based on the results of limited tests, a suitable composition of FA, GP and GGBS for constant quantity of CA and $\mathrm{fA}$ has been obtained to produce geopolymer concrete of $\mathrm{M}_{32}$. It is found that geopolymer concrete is $14 \%$ cheaper than concrete of the same strength using OPC. The strength gain in the case of geo-polymer concrete is rather slow compared to that of Portland cement concrete. Tensile strength of this concrete was also determined by conducting flexure test on beams prepared using this concrete. During curing, up to 7days, greyishwhite powder used to come out from all the surfaces of sample and it was found to be a mixture of Carbonates and Sulphides of $\mathrm{Na}, \mathrm{Mg}$ and Fe. Detailed investigation is necessary to arrive at an optimum mixture composition for producing Geo-polymer concrete of required strength. Effect of greyish-white powder on the strength and durability of the concrete is to be studied.

Keywords: Geopolymer, industrial waste, green material, cost effective material, eco-friendly material.

\author{
Dr. N. Bhavanishankar Rao \\ Professor, Dept. of civil Engineering, NMAMIT, \\ Nitte, Karkala-574110, India
}

\section{INTRODUCTION}

A. Scope for study

Industrialization and uncontrolled exploitation of natural resources has lead to the formation of large quantity of industrial waste materials which pose problem of disposing such materials and environmental pollution. Fly ash from thermal projects, GGBS from steel industries, broken glass from building industries and quarry dust from granite quarries are examples of industrial waste materials posing problems. These are to be recycled / reused properly instead of disposing them as waste materials. Considerable research is taking place throughout the world in developing suitable technologies for proper utilisation of these industrial waste materials. An attempt made in this regard is presented in this paper.

Davidovits 1994), (2005) suggested that an alkaline liquid could be used to react with Silicon ( $\mathrm{Si}$ ) and Aluminium (Al) in a source material of geological origin or in by-product materials such as fly ash to produce a good binder or cementing material. He named this binder as "Geopolymer" because the chemical reaction that takes place is a polymerisation process. Geopolymer is belonging to the family of inorganic polymers and the process involves a substantially fast chemical reaction under alkaline condition on $\mathrm{Si}-\mathrm{Al}$ minerals.

The main constituents of geopolymer are an alkaline liquid and source materials. The source materials should be rich in Silicon and Aluminium. They could be natural minerals such as clays, metakaolin a product of kaolin clay or by-product materials such as fly ash (FA), silica fume (SF), Sodium silicate, ground granulated blast furnace slag (GGBS), ricehusk ash (RHA) etc. Alkaline liquid is Sodium hydroxide solution. 
International Journal of Engineering Trends and Technology (IJETT) - Volume 19 Number 2 - Jan 2015

Geopolymer concrete can be produced using low-calcium fly ash obtained from thermal power plants where it is formed as a by-product of burning anthracite or bituminous coal. Coarse and fine aggregates used for making Portland cement concrete can also be used to make geopolymer concrete. Sodium hydroxide with $97 \%-98 \%$ purity in the form of flakes is commercially available which can be dissolved in water to have concentration in the range of 8 molar to 16 molar. Mass of $\mathrm{NaOH}$ required depends on the concentration required. $\mathrm{NaOH}$ solution with concentration of 8molar requires $8 \times 40=320$ grams of $\mathrm{NaOH}$ flakes per litre of water. In order to improve the workability of the geopolymer concrete, a water reducer super plasticizer or extra water may be added to the mixture. The constituent materials can be mixed thoroughly using appropriate method or approach to obtain geopolymer concrete of required consistency or slump.

\section{B. Objective of the Study}

The objective of the study was to quantify the effects of adding glass powder and GGBS which are industrial waste materials, on the compressive strength of fly ash based geopolymer concrete. Generally, geopolymer concrete is cured under high temperature to get increased strength in a short period which involves additional cost and input of additional energy. Hence, the gain in the strength due to air curing of this concrete under room temperature only was considered in this study.

\section{Research Significance}

Geopolymer concrete has shown great potential in use for construction purposes. In the literature, use of several costly constituents has been suggested to increase the strength of this concrete. In many of the studies, it is shown that the curing under high temperature $\left(60^{\circ} \mathrm{C}\right.$ to $\left.100^{\circ} \mathrm{C}\right)$ is required to attain the strength in the range of $60 \mathrm{~N} / \mathrm{mm}^{2}$ to $80 \mathrm{~N} / \mathrm{mm}^{2}$. For practical applications, it is necessary to identify cheaper and effective constituent materials and obtain strength in the range $\mathrm{M}_{30}$ to $\mathrm{M}_{50}$ without going for heating which is a laborious and costly process. Thus the geopolymer concrete can be made economical, popular, attractive and convincing the people in the construction field. Use of a few cheaper constituents indicated the possibility of attaining compressive strength up to $\mathrm{M}_{30}$ without using plasticizer. Further improvement is possible using better mixture design and reducing water content using plasticizer or super plasticizer. Such studies are in progress

\section{EXPERIMENTAL INVESTIGATION}

A. Selection of constituent materials

It is well established that the constituents for geopolymerization should consist sufficiently large amount of Silicon and Aluminium oxides which should be soluble in an alkaline solution to form reactive $\mathrm{Si}$ and $\mathrm{Al}$. FA consists of aluminosilicate and is selected as an important source material for $\mathrm{Si}$ and $\mathrm{Al}$. However, it is necessary to have additional material which can provide more reactive silica $\mathrm{Si}$ and $\mathrm{Al}$ at a reasonable cost. Caijun Shi et al, (2005) and Bajad et al, (2012) reported that Glass powder finer than 600micron becomes reactive silica. Hence, it can be used as an additional source for Si. The chemical analysis of available FA indicated low percentage (less than 9\%) of Aluminium oxide. In order to increase the amount of $\mathrm{Al}$ in geopolymer, GGBS can be added as an additional source for Al. The above facts were considered in selecting materials for the experimental study reported in this presentation.

\section{B. Materials used}

The materials used in the study are: 1) Fly ash (FA), (2) Glass powder (GP), (3) GGBS, (4) NaOH flakes, (5) Fine aggregate fA, (6) Coarse aggregate CA and (7) Water (W). Details of these materials are given below.

\section{Fly-ash}

Fly-ash from a thermal plant (Udupi Power Corporation Ltd) close to our Institute was collected, sieved using 600 micron IS sieve and used for the experiment. Major components of Fly ash was found to be Silica $\left(\mathrm{SiO}_{2}\right)=80.2 \%$, Alumina $\left(\mathrm{Al}_{2} \mathrm{O}_{3}\right)=8.7 \%$ and Iron Oxide $\left(\mathrm{Fe}_{2} \mathrm{O}_{3}\right)=2.8 \%$. Its specific gravity was found to be 2.38 .

\section{Glass Powder}

Glass powder was obtained by crushing available waste glass pieces using a crusher and the powder passing through 
International Journal of Engineering Trends and Technology (IJETT) - Volume 19 Number 2 - Jan 2015

600micron IS sieve was used in the investigation.

\section{GGBS Powder}

This powder available in market was collected, sieved using 600 micron IS sieve and used for the experiment. Its specific gravity was found to be 2.88 .

\section{Aggregate}

Coarse aggregate with $20 \mathrm{~mm}$ down, having $\mathrm{FM}=6.67$ and specific gravity $=2.72$ was used. Fine aggregate having $\mathrm{FM}=$ 2.48 and specific gravity $=2.63$ was used.

\section{Alkaline Liquid}

Commercially available $\mathrm{NaOH}$ flakes dissolved in drinking or potable water was used as alkaline liquid.

\section{Mix Proportion}

Since there is no standard procedure for designing the mix proportion, considering the information available in literature, the following steps were used for designing required mix for experimental investigation. Using the results of sieve analysis of course and fine aggregates four trial mixes of aggregates were selected and these mixes were used for determining maximum bulk density. From the trials it was found that mix with mass ratio of $\mathrm{CA} / \mathrm{fA}=0.522$ gives maximum density. Mass ratios for other materials were selected based on the information available in literature. Hence,

. The mass ratio CA/fA is 0.522

$\mathrm{NaOH} / \mathrm{FA}$ or $\mathrm{NaOH} /(\mathrm{FA}+\mathrm{GP})$ or $\mathrm{NaOH} /(\mathrm{FA}+\mathrm{GP}+\mathrm{GGBS})$ was taken as $7.50 \%$

$\mathrm{W} / \mathrm{FA}$ or $\mathrm{W} /(\mathrm{FA}+\mathrm{GP})$ or $\mathrm{W} /(\mathrm{FA}+\mathrm{GP}+\mathrm{GGBS})$ was taken as 0.3 The mass ratio for different batches of concrete, $(\mathrm{CA}+\mathrm{fA}) / \mathrm{FA}$, $(\mathrm{CA}+\mathrm{fA}) / \quad(\mathrm{FA}+\mathrm{GP}),(\mathrm{CA}+\mathrm{fA}) / \quad(\mathrm{FA}+\mathrm{GP}+\mathrm{GGBS}) \quad$ was maintained as 3.5

Variables considered were:

. GP/ FA $0 \%, 5 \%, 10 \% 15 \%$ and $20 \%$

. GGBS/FA $0 \%, 5 \%, 10 \%, 15 \%, 20 \%$, with GP/FA as $10 \%$

Nine different mixes were considered and totally 54 cubes were cast.

\section{PRODUCTION OF TEST SAMPLES}

Quantities of different constituents required for making required number of cubes of $15 \mathrm{~cm}$ size were calculated for different mixes and recorded. Sodium hydroxide flakes of $0.75 \mathrm{~kg}$ were dissolved in 2.978 litre of water to form an alkaline solution. Selected amount of FA or $(F A+G P)$ or (FA+GP+GGBS) as the case may be added to $\mathrm{NaOH}$ solution and mixed properly for about 10minutes to form a homogeneous geo-polymer paste. This paste was added to premixed aggregate $(\mathrm{CA}+\mathrm{fA})$ quantity placed on a GI sheet of $1 \mathrm{~m} \times 2 \mathrm{~m}$ size. All the materials were mixed properly to obtain a homogeneous and cohesive geopolymer concrete. In order to increase the workability, an additional quantity of 0.9 litre water was added and mixed properly. The concrete so prepared was placed in to steel cubes of $15 \mathrm{~cm}$ size, compacted using standard tamping rod, levelled and kept in an isolated place for air curing at room temperature in the laboratory. Demolding of samples after 24 hours was not possible as they were not hard enough. Hence, after 3 days, the concrete cubes were removed from the mould and cured in air till they were tested.

In the first stage polymer paste was prepared by mixing FA and $\mathrm{NaOH}$ solution and in the second stage mixture of FA and different $\%$ of GP was used to mix with $\mathrm{NaOH}$ solution to prepare the paste. In the third stage, mixture of FA, 10\% GP and different $\%$ of GGBS was used to mix with $\mathrm{NaOH}$ solution to prepare the paste.

When the cubes were tested after 7 days of curing, the strength obtained for concrete having FA and 10\% GP was found to be the highest. Hence, it was decided to prepare concrete having FA, 10\% GP and different percentages of GGBS to study the effect of GGBS on the strength of geopolymer concrete.

In order to study the tensile strength of concrete having (FA+GP+GGBS), the mix which gave the maximum compressive strength for 28 days of curing was used to cast beams of $15 \mathrm{~cm}, 15 \mathrm{~cm}$ and $50 \mathrm{~cm}$ size and cured for 28 days before testing,

During curing period greyish white powder was coming out from all surfaces. When it was wiped out after 7 days using wet cotton waste, it was stopped. This powder was subjected 
International Journal of Engineering Trends and Technology (IJETT) - Volume 19 Number 2 - Jan 2015

to chemical analysis.

\section{TESTS CONDUCTED}

Cube samples were weighed after air curing for 7 and 28 days and tested for compressive strength using compression testing machine of $2000 \mathrm{KN}$ capacity in accordance with the procedure mentioned in IS 516- 1959.

Beam samples were tested after 28 days of curing using "Two point loading" in universal testing machine of 40 tonnes capacity.

Small pieces of failed concrete cubes were used for finding their water absorption as per IS 2386 (Part III) 1963.

\section{EXPERIMENTAL RESULTS AND DISCUSSION}

\section{A. Presentation of Results}

Results of compression tests are shown in Table 1 and Table 2 and they are also depicted in Fig.1 to Fig.3. Variation in unit weight of cubes and water absorption in $\%$ are shown in Table 3 and Table 4 . Average flexural strength of beam was found to be $2.1 \mathrm{~N} / \mathrm{mm}^{2}$.

White powder coming out from the surfaces of samples was found to be Carbonates and Sulphides of Sodium ( NA), Magnesium $(\mathrm{Mg})$ and Fe from the chemical analysis.

Table 1: Variation in Compressive Strength of Cubes in MPa For (FA+GP)

\begin{tabular}{|l|l|l|l|l|l|}
\hline $\begin{array}{l}\text { Replacement } \\
\text { of FA by GP }\end{array}$ & $0 \%$ & $5 \%$ & $10 \%$ & $15 \%$ & $20 \%$ \\
\hline $\begin{array}{l}7 \quad \text { Days } \\
\text { Compressive } \\
\text { Strength }\end{array}$ & 4.22 & 5.45 & 6.67 & 4.89 & 5.34 \\
\hline $\begin{array}{l}28 \quad \text { Days } \\
\text { Compressive } \\
\text { Strength }\end{array}$ & 13.1 & 14.32 & 15.56 & 16.67 & 20.89 \\
\hline
\end{tabular}

Table 2 : Variation in Compressive Strength of Cubes in MPa For (FA+10\%

\begin{tabular}{|l|l|l|l|l|l|}
\multicolumn{7}{|c|}{ GP+ GGBS) } \\
$\begin{array}{l}\text { Replaceme } \\
\text { nt of FA by } \\
\text { GP }\end{array}$ & $0 \%$ & $5 \%$ & $10 \%$ & $15 \%$ & $20 \%$ \\
\hline $\begin{array}{l}7 \quad \text { Days } \\
\text { Compressiv } \\
\text { e Strength }\end{array}$ & 6.67 & 8.33 & 12.45 & 16.67 & 17.33 \\
\hline $\begin{array}{l}28 \quad \text { Days } \\
\text { Compressiv } \\
\text { e Strength }\end{array}$ & 15.56 & 20.00 & 25.22 & 32.44 & 32.89 \\
\hline
\end{tabular}

Table 3: Variation in Unit Weight of Cubes and Water absorption-FA+GP

\begin{tabular}{|l|l|l|l|l|l|}
\hline $\begin{array}{l}\text { Replace } \\
\text { ment of } \\
\text { FA by } \\
\text { GP }\end{array}$ & $0 \%$ & $5 \%$ & $10 \%$ & $15 \%$ & $20 \%$ \\
\hline $\begin{array}{l}\text { Unit } \\
\text { weight in } \\
\text { kg }\end{array}$ & 8.15 & 8.13 & 8.11 & 8.05 & 7.97 \\
\hline $\begin{array}{l}\text { Water } \\
\text { absorptio } \\
\text { n in \% }\end{array}$ & 6.0 & 6.0 & 6.7 & 6.0 & 7.0 \\
\hline
\end{tabular}

Table 4 :Variation in Unit Weight of Cubes and Water absorption-FA+ $10 \%$ GP+ GGBS

\begin{tabular}{|l|l|l|l|l|}
\hline $\begin{array}{l}\text { Replacement } \\
\text { of FA by } \\
\text { GGBS }\end{array}$ & $5 \%$ & $10 \%$ & $15 \%$ & $20 \%$ \\
\hline $\begin{array}{l}\text { Unit weight in } \\
\mathrm{kg}\end{array}$ & 7.95 & 8.005 & 8.055 & 8.074 \\
\hline $\begin{array}{l}\text { Water } \\
\text { absorption in } \\
\%\end{array}$ & 6.6 & 6.2 & 6.3 & 5.5 \\
\hline
\end{tabular}

\section{B. Discussion of Results}

Fig.1 clearly shows that the 7days cube strength increases as the replacement of FA by GP increases up to $10 \%$ and then slightly decreases. However, the 28days cube strength is increasing as the replacement of FA by GP increases up to $15 \%$ and then becomes almost constant. Since the 7days strength decreased after 10\%, it was decided to use $10 \%$ replacement by GP and further replacement by GGBS.

Fig. 2 shows the influence of replacement of FA by GGBS with $10 \%$ replacement of FA by GP. It is observed that both 7 days and 28 days strength increase continuously up to $15 \%$ replacement and afterwards the increase is small ie $1.4 \%$ to $4 \%$ respectively. Hence, the replacement up to $15 \%$ appears to be optimum and further increase is not much useful from the strength point of view. It is also observed from this figure that 7 days strength is $30 \%$ to $50 \%$ of 28 days strength where as it will be about $70 \%$ for Portland cement concrete. Thus, the strength gain in the case of geo-polymer concrete is rather slow compared to that of Portland cement concrete. 


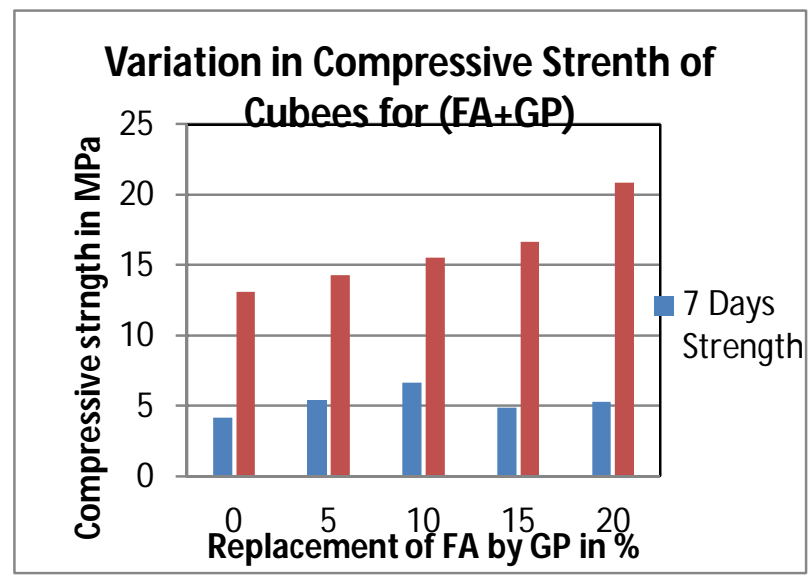

Figure 1: Compressive Strength of Cubes: FA+GP



Figure 2: Compressive Strength of Cubes: FA + 10\% GP + GGBS

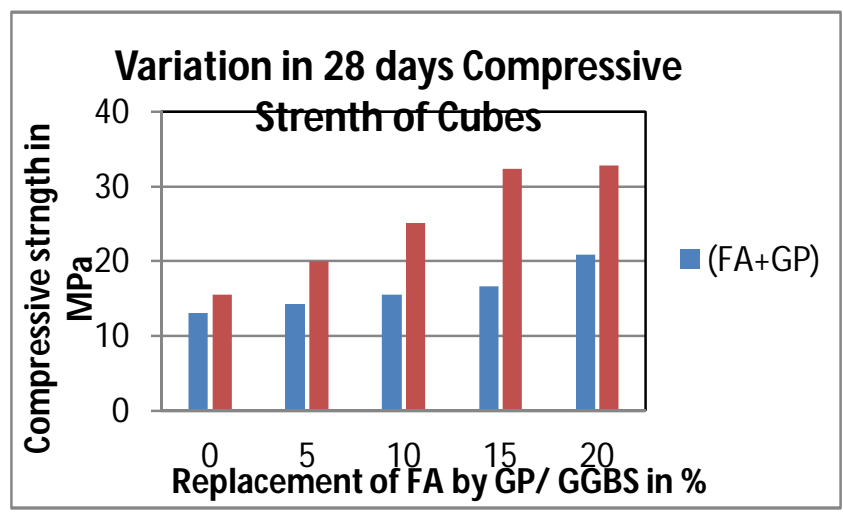

Figure 3 : Comparison of 28 days Strength for two mixes
Fig.3 depicts a comparison of 28days strength for mixes without GGBS and with GGBS. Use of GGBS is certainly useful in increasing the strength of Geo-polymer concrete with $10 \%$ replacement of FA by GP. However, it is necessary to investigate the effect of $15 \%$ replacement of FA by GP and replacement of FA by GGBS which may help in arriving at an optimum mixture of industrial waste materials for Geopolymer concrete.

Table 3 shows that the unit weight of cubes decrease gradually as the replacement of FA by GP increases. But, from the Table 4, it is seen that unit weight of cubes increases with increase in replacement of FA by GGBS with constant value of GP. This is due to the difference in specific gravity of GP and GGBS compared to FA. Water absorption of Geo-polymer concrete is observed to be almost constant for both the mixes as depicted in the Table 3 and Table 4.

These results clearly show that Geopolymer concrete with compressive strength of $30 \mathrm{Mpa}$ and water absorption less than $7 \%$ can be easily obtained using industrial waste materials without using Sodium Silicate, Silica fume (costly materials) or heating to higher temperature (costly process).

\section{COST ANALYSIS}

Comparison of cost of producing $1 \mathrm{M}^{3}$ of concrete using Portland cement and geo-polymer concrete used is shown in the following Tables

Table 5: Cost of $1 \mathrm{M}^{3}$ Portland cement concrete of $\mathrm{M}_{30}$ as per IS 10262

\begin{tabular}{|l|l|l|l|}
\hline Material & $\begin{array}{l}\text { Quantity } \\
/ 1 \mathrm{M}^{3}\end{array}$ & Rs / unit & Cost in Rs \\
\hline Cement & $465 \mathrm{~kg}$ & $6.8 / \mathrm{kg}$ & 3162.00 \\
\hline $\begin{array}{l}\text { Fine } \\
\text { aggregate }\end{array}$ & $0.395 \mathrm{~m}^{3}$ & $1000 / \mathrm{m}^{3}$ & 395.00 \\
\hline $\begin{array}{l}\text { Coarse } \\
\text { aggregate }\end{array}$ & $0.762 \mathrm{~m}^{3}$ & $1220 / \mathrm{m}^{3}$ & 937.26 \\
\hline Water & $\begin{array}{l}192.69 \\
\text { Litre }\end{array}$ & $0.5 / \mathrm{Litre}$ & 96.35 \\
\hline
\end{tabular}


International Journal of Engineering Trends and Technology (IJETT) - Volume 19 Number 2 - Jan 2015

Table 6 Cost of $1 \mathrm{M}^{3}$ geo-polymer concrete of $\mathrm{M}_{32}$

\begin{tabular}{|l|l|l|l|}
\hline Material & $\begin{array}{l}\text { Quantity } \\
/ 1 \mathrm{M}^{3}\end{array}$ & Rs / unit & $\begin{array}{l}\text { Cost in } \\
\text { Rs }\end{array}$ \\
\hline Fly ash & $367.33 \mathrm{~kg}$ & $2 / \mathrm{kg}$ & 734.66 \\
\hline $\begin{array}{l}\text { Glass } \\
\text { powder }\end{array}$ & $48.98 \mathrm{~kg}$ & $1 / \mathrm{kg}$ & 48.98 \\
\hline $\mathrm{G} \mathrm{G} \mathrm{B} \mathrm{S}$ & $73.47 \mathrm{~kg}$ & $4 / \mathrm{kg}$ & 293.88 \\
\hline $\begin{array}{l}\mathrm{NaOH} \\
\text { Flakes }\end{array}$ & $36.74 \mathrm{~kg}$ & $40 / \mathrm{kg}$ & 1469.60 \\
\hline $\begin{array}{l}\text { Fine } \\
\text { aggregate }\end{array}$ & $0.391 \mathrm{~m}^{3}$ & $1000 / \mathrm{m}^{3}$ & 391.00 \\
\hline $\begin{array}{l}\text { Coarse } \\
\text { aggregate }\end{array}$ & $0.751 \mathrm{~m}^{3}$ & $1220 / \mathrm{m}^{3}$ & 916.22 \\
\hline \begin{tabular}{l} 
Water \\
\hline
\end{tabular} & $\begin{array}{l}191.5 \\
\text { Litre }\end{array}$ & $0.5 / \mathrm{Litre}$ & 95.75 \\
\hline
\end{tabular}

From the above tables, it is observed that geo-polymer concrete is $14 \%$ cheaper than conventional concrete.

\section{CONCLUSIONS}

Geopolymer concrete was produced using available industrial waste materials (FA, GP, GGBS), Sodium Hydroxide as activating solution, fine aggregate and coarse aggregate. Different proportions of waste materials were considered to prepare the mixes. Cubes of $150 \mathrm{~mm}$ size were prepared from each mix, cured in air at laboratory temperature and tested for compressive strength. Based on the results the following conclusions are drawn:

1. Use of FA and Sodium Hydroxide in making Geopolymer concrete is not sufficient to obtain required strength.

2. Replacement of FA by GP up to $15 \%$ is useful in increasing compressive strength up to $20 \mathrm{Mpa}$.

3. 10\% replacement of FA by GP and further replacement of FA by GGBS up to $15 \%$ increases the strength of concrete up to $32 \mathrm{Mpa}$.

4. Water absorption of concrete made with different $\%$ of FA, GP, and GGBS is found to be almost constant.

5. Geopolymer concrete with compressive strength of 30Mpa and water absorption less than $7 \%$ can be obtained using only industrial waste materials without using Sodium Silicate or heating to higher temperature.

6.In all the mixes used, a greyish white powder which was coming out from all the Surfaces of cube sample /beam sample, during initial periods of curing is found to be a mixture of bicarbonates of Sodium, Magnesium and sulphides of Iron.

7.Geo-polymer concrete is about $14 \%$ cheaper compared to concrete using PC.

\section{ACKNOWLEDGMENT}

Experimental work was carried out using the facilities in Civil Engineering Department Laboratory of N.M.A.M Institute of Technology, Niite. The authors wish to thank the authorities of N.M.A.M Institute of Technology for their kind support and encouragement.

\section{REFERENCES}

[1] Davidovits J, Properties of Geopolymer cements, First International Conference on Alkaline Cements and Concretes (pp 131 -149), Kiev, Ukraine: Kiev State Technical University 1994.

[2] Davidovits J, Green Chemistry, Sustainable Development and False ideas About Geopolymer Concrete, International Workshop on Geopolymers and Geopolymer Concrete, Perth, Australia, 2005.

[3] Caijun Shi, Yanzhhong Wu,Chris Riefler andHugh Wang, "Characteristics and Pozzolanic reactivity of Glass powders", Cement and Conc. Res., Vol. 35, 2005, pp 987-993

[4] Bajad M.N, Modhera C.D and A.K.Desai, Higher Strength Concrete Using Glass Powder. Journal of Structural Engineering Vol.39, Number 3 Aug. 2012

[5] Ramlan. A.G, Albert Oomman Roy, Sujan Kumar, Sherin Rajan and Supreetha. "Geo-Polymer Concrete Using Industrial Waste" Project Report Submitted to V T U in Partial Fulfillment for the Award of B E Degree in Civil Engineering. (April,2013) 